\title{
System archetypes to understand the impacts of climate change on rice production: A case study in West Nusa Tenggara, Indonesia
}

Author: Muhamad Khairul Bahri,

Victoria University of Wellington, Wellington School of Business and Government, 33 Bunny Street, Pipitea, Wellington 6011, New Zealand

Email:mkhairulbahri@ymail.com

\begin{abstract}
Climate projections show that southern Indonesia such as West Nusa Tenggara is projected to experience a lower precipitation and higher temperatures. To date, research on climate change impact on Indonesian rice production yield is limited. As climate change is projected to decrease rainfall and to increase temperatures, this paper offers a qualitative analysis using system archetypes to understand the impacts of climate change on rice production. Two system archetypes are identified including Limits to Growth and Success to Successful. Both archetypes explain that rice production is hampered by high minimum temperature as photosynthesis output is decreased by increasing respiration. This paper shows that using a simple tool, system archetypes, we can describe the impacts of climate change on rice production. The outputs of this study such as a causal loop diagram and system archetypes can be a basis to develop a simulation model in understanding the impacts of climate change on main crops.
\end{abstract}

Keywords: system archetypes; rice production; system dynamics; climate change; Indonesia rice 


\section{Introduction}

Rice farming is an important sector for economic development, particularly in developing countries (FAO, 2003; GRIsP, 2013; IFRRI, 2009). The importance of rice farming attracts developing countries to support rice production through some facilities. In Indonesia, the government has induced some programs to enhance rice production, achieving rice self-sufficiency. For example, the aid program for farmers has continuously provided subsidies such as fertilizers, pesticides and high-quality seeds (Hadi, \& Susilowati, 2010). As a result, Indonesian rice production has increased gradually by $3 \%$ a year since 2007 (Maulana et al., 2010; Iswari, 2013).

Figure 1 shows that rice is planted in across the world. However, rice is mostly planted in developing countries, i.e. low and middle-income countries (GRIsP, 2013), especially in Asian regions which make up approximately $90 \%$ of total rice production (GRIsP, 2013). It is stated that rice is consumed by about 3 billion people, confirming that a significant proportion of the world population will depend on rice by 2035 (IRRI, 2015). 


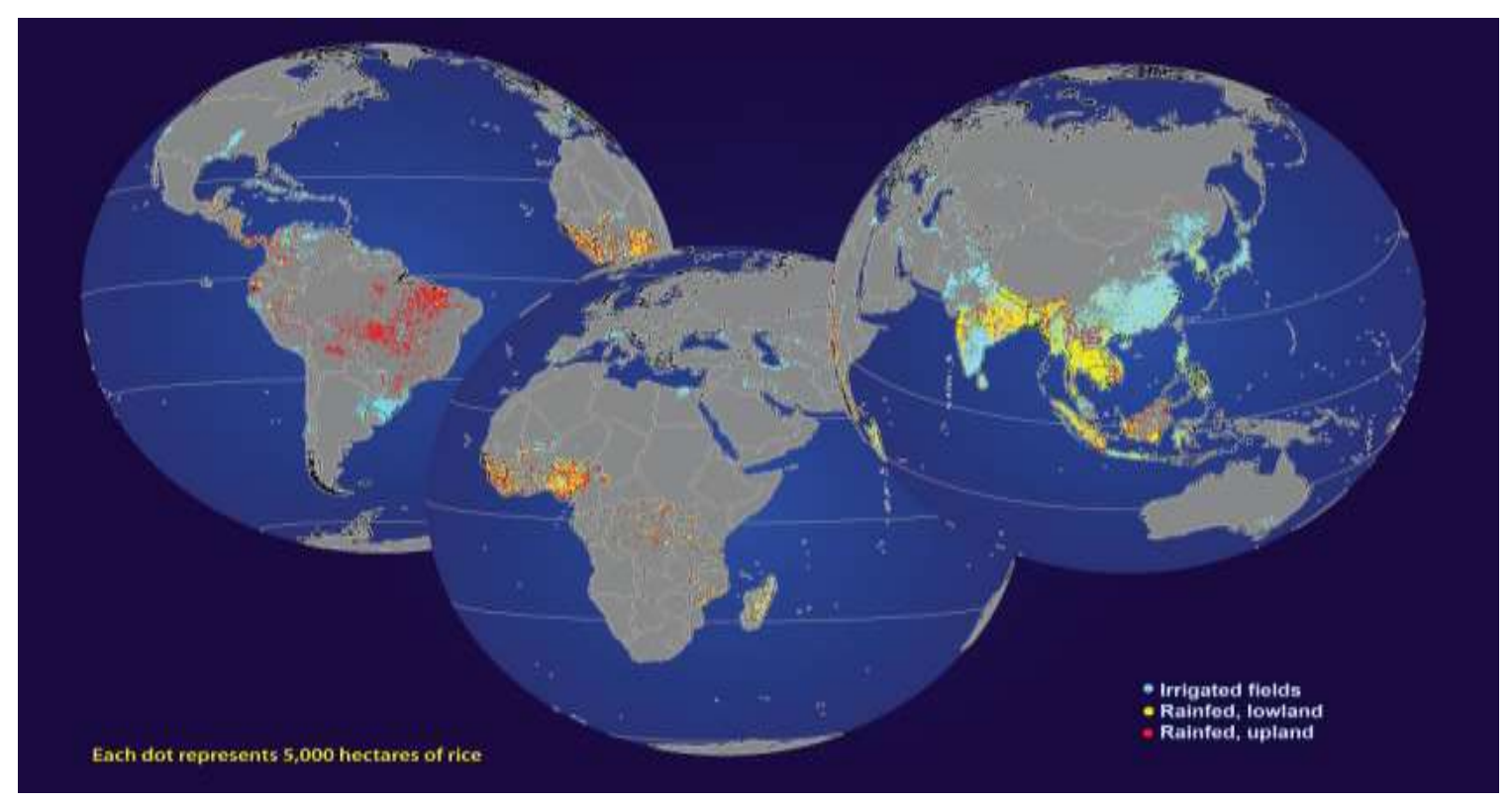

Figure 1. Major rice-growing areas across the world (GRIsP, 2013)

In general, rice grows well within its optimum temperature (e.g. Yoshida, 1981). Beyond its optimum temperature, the high temperature tends to negatively influence rice yield (e.g. Yoshida, 1981). In other words, rice yields gradually increase up to their temperature thresholds, but rice yield tends to decrease above rice's temperature thresholds (Ackerman \& Stanton, 2012; Yoshida, 1981).

Despite its importance to the economy, rice is relatively vulnerable to climate change as climate change is manifested as high temperature and rainfall change. An existing study (Devkota, 2011; Welch et al., 2010) explains that the recent maximum temperature in Asian regions is close to the maximum temperature threshold of rice. This is exacerbated by the negative impacts of high minimum temperature on rice as observed minimum temperature higher than the threshold of minimum temperature (Peng et al., 2004; Welch et al., 2010). 


\subsection{Previous research and a research gap}

Rice production in almost all Indonesian province is highly affected by precipitation (Naylor et al., 2001, 2002; Roberts et al., 2004). Water sources for rice farming such as reservoirs and rivers highly depend on precipitation so that a lower rainfall because of climate change could directly affect rice production in Indonesia (Sumarno et al., 2008).

As Indonesia is vulnerable to ENSO (El Nino Southern Oscillation), many scholars explore the impacts of ENSO on Indonesian rice production. For example, using statistical models, existing studies conclude that Indonesian rice is vulnerable to ENSO (El-Nino Southern Oscillation) as ENSO could significantly reduce rainfall and delay rice planting seasons (Naylor et al., 2001, 2002; Roberts et al., 2004; Naylor \& Mastrandrea, 2009).

In addition, several studies try to explain the impacts of climate change on Indonesian rice production (Naylor et al., 2007). Naylor et al. (2007) claim that Indonesia is projected to be vulnerable to climate change as the country would experience a lower precipitation in the future. To anticipate impacts of climate change, that study (Naylor et al., 2007) suggests that Indonesia should prepare some adaptations to climate change such as better irrigation facilities, drought-tolerant rice varieties, and alternative staple foods.

Although there are existing studies that explore the impacts of climate variability on Indonesian rice production, those studies have limitations. The first limitation is existing studies focused only either on the impacts of ENSO or the impacts of precipitation change on rice production. This paper intends to fill this gap by explaining the negative impacts of precipitation and temperature change on rice production. 
Furthermore, because developing countries have limited resources to tackle the negative impacts of climate change, understanding the negative impacts of climate change on rice production is important (GRIsP, 2013, IFRRI, 2009). Thus, this paper aims to describe the negative impacts of climate change on rice production, especially in developing countries. Possible solutions in coping the impacts of climate change will be also explained.

\section{A case study: Rice production in West Nusa Tenggara}

Figure 2 shows the geographical location of West Nusa Tenggara (WNT). Figure 2a shows that all Indonesia provinces (33 provinces), from Aceh in western Indonesia to Papua in eastern Indonesia and West Nusa Tenggara is located in southern Indonesia and surrounded by Bali in West and East Nusa Tenggara (ENT) in East.

WNT consists of two main islands, Lombok and Sumbawa as seen in figure $2 \mathrm{~b}$. Again, WNT is located in eastern Indonesia at $115^{0} 46^{\prime}-119^{0} 5^{\prime}$ East Longitude and $8^{0}$ $10^{\prime}-9^{0} 5^{\prime}$ South Latitude (BPS NTB, 2010). The average maximum temperature ranges from $30^{\circ} \mathrm{C}$ to $32^{\circ} \mathrm{C}$ (the highest temperature is in November), while the minimum temperature varies on average between $21^{\circ} \mathrm{C}$ and $25^{\circ} \mathrm{C}$ (the lowest temperature is in June or July). The maximum temperature in the rainy seasons is about $31^{\circ} \mathrm{C}$, whereas the minimum temperature in the rainy seasons is about $22^{\circ} \mathrm{C}$. The relative humidity is between $74 \%$ and $81 \%$ with the annual rainfall about $1,600 \mathrm{~mm}$. A summary of observed climate is given in table 1. 


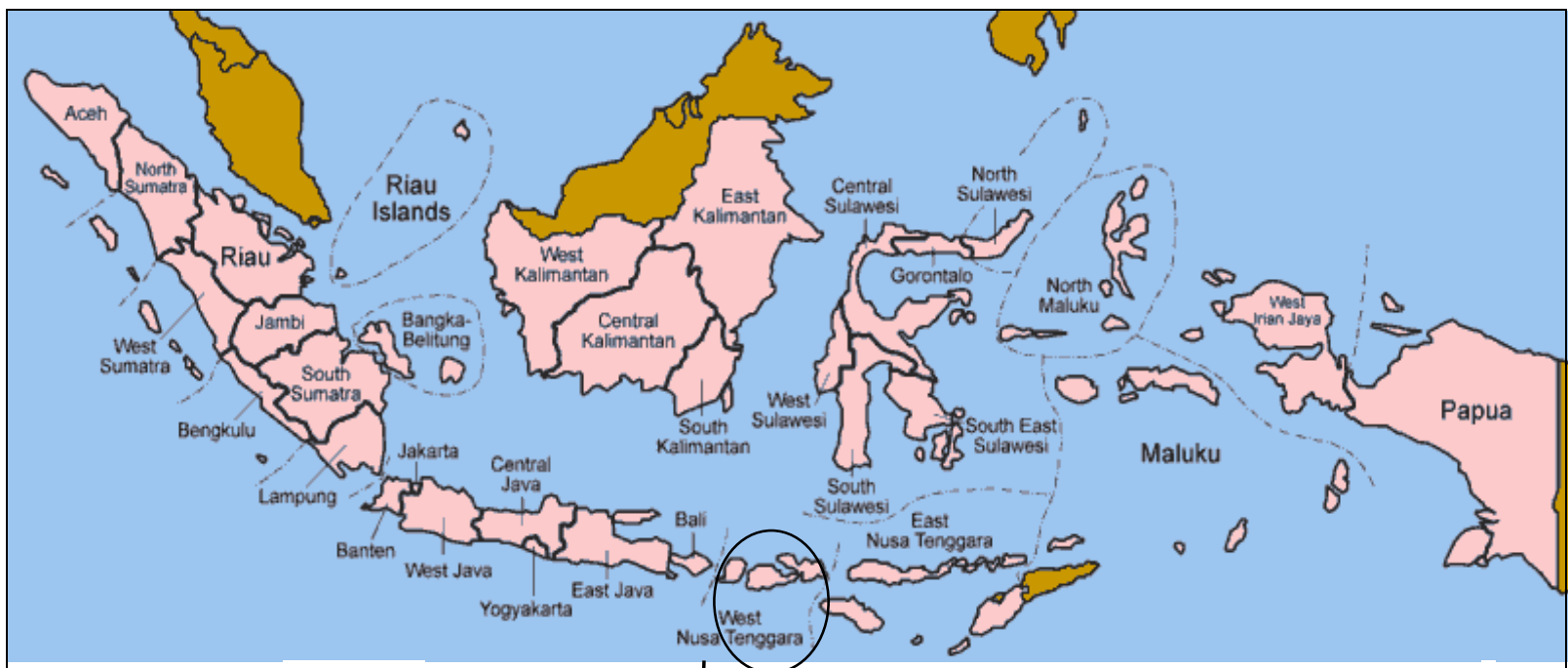

a. Indonesia (source: http://www.indohesiamatters.com/86/indonesian-provinces-map/)

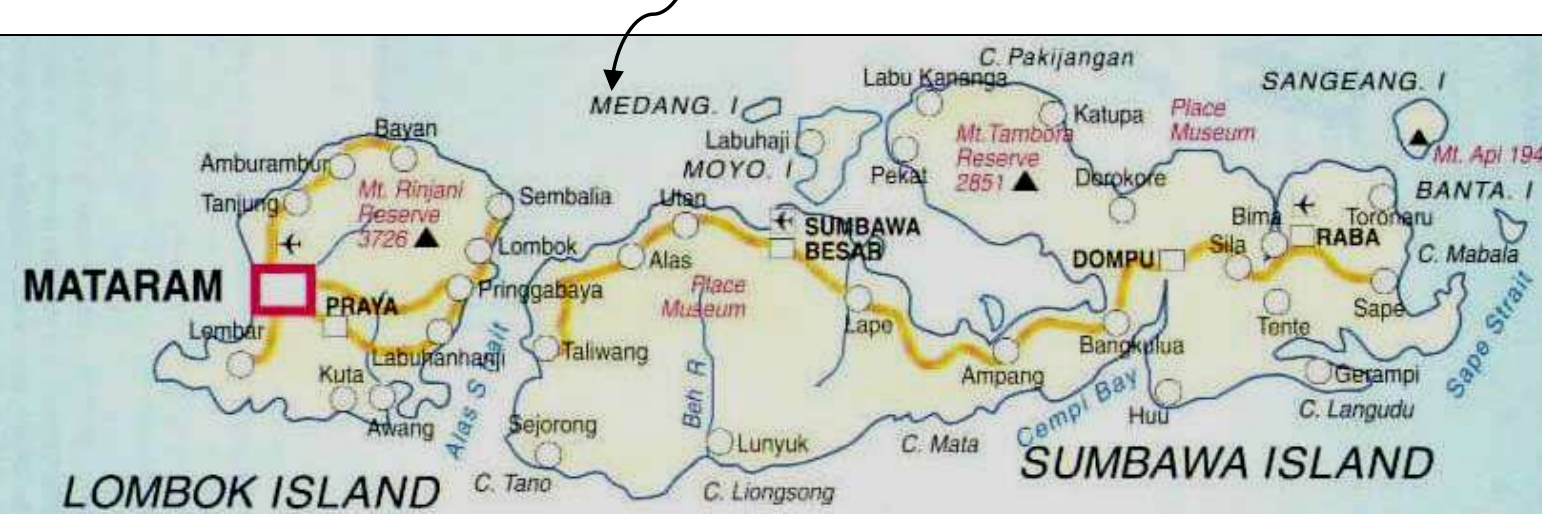

\section{WEST NUSA TENGGARA}

b. West Nusa Tenggara (source: http://indonesianlombokernas.com/west-nusa-tenggara/)

Figure 2. Indonesia and West Nusa Tenggara

\begin{tabular}{|l|c|c|c|}
\hline Data Distribution & $\begin{array}{c}\text { Seasonal } \\
\text { Rainfall }\end{array}$ & $\begin{array}{c}\text { Seasonal Minimum } \\
\text { Temperature }\end{array}$ & $\begin{array}{c}\text { Seasonal Maximum } \\
\text { Temperature }\end{array}$ \\
\hline Mean & 1,658 & 22.9 & 31.1 \\
\hline Standard deviation & 318 & 0.4 & 0.5 \\
\hline Percentile 25\% & 1,412 & 22.6 & 30.8 \\
\hline Percentile 50\% & 1,571 & 22.9 & 31.0 \\
\hline
\end{tabular}

6| Pag e 


\begin{tabular}{|l|c|c|c|}
\hline Percentile 75\% & 1,839 & 23.1 & 31.4 \\
\hline Ranges (min-max) & $(1,000-1,850)$ & $(22-24)$ & $(30-32)$ \\
\hline
\end{tabular}

Table 1. Data distribution of climate (BMKG NTB, 1971-2012)

It is important in this study to explain the importance of rice. Figure 3 shows that rice is the most consumed food in WNT (about 25\% of total food consumption), following by prepared food and beverages (about $20 \%$ of total food consumption). This also means that rice is the main source of energy and protein for people in WNT (Pemerintah Nusa Tenggara Barat, 2011).

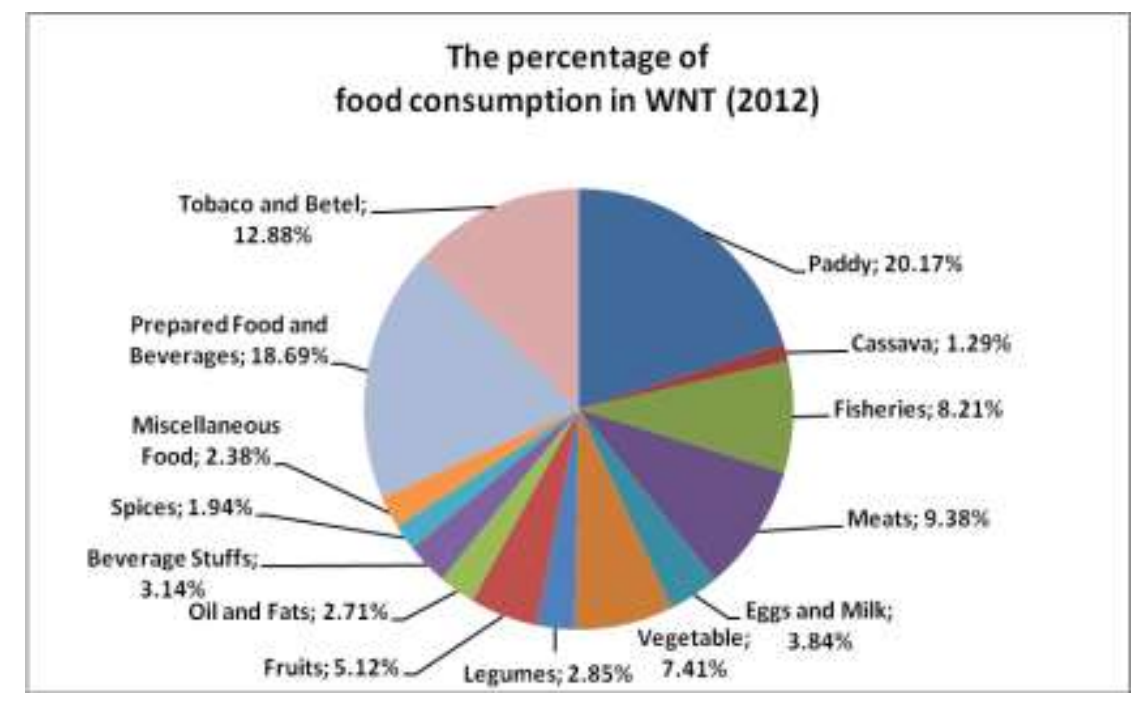

Figure 3. The percentage of food consumption in WNT (BPS NTB, 2013)

The importance of rice in WNT also founded in terms of Gross Domestic Product (GDP) and employment as seen in figure $4 \mathrm{a}$ and figure $4 \mathrm{~b}$ respectively. As shown in figure 5, agriculture has the highest GDP contribution (29\% of GDP) and the highest total employment contribution in WNT (about 45\%). Likewise, agriculture contributed between $44 \%$ and $47 \%$ to employment in the period 2007-2013 (BPS NTB, 2014). This 7 | P a g e 
evidence shows that agriculture is a highly important sector for West Nusa Tenggara. Please bear in mind that rice covers almost $65 \%$ of agriculture activity in WNT (BPS NTB, 2014).

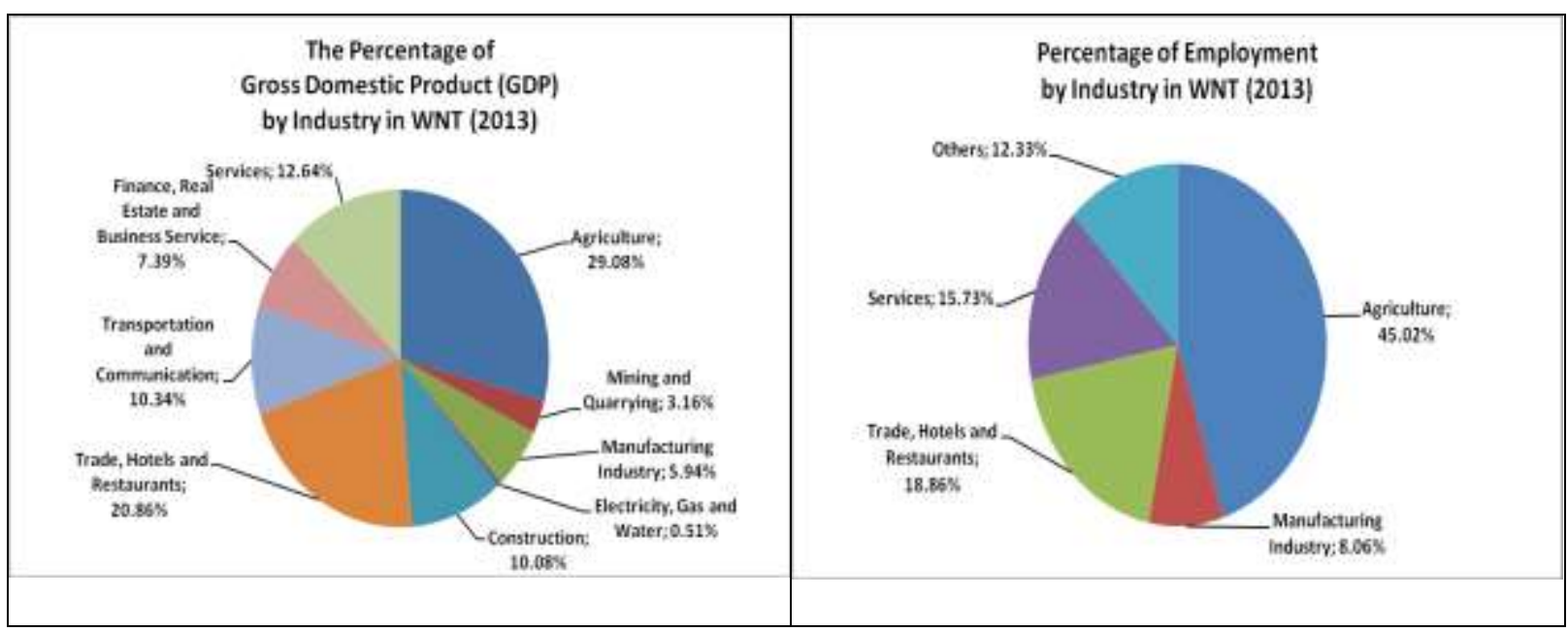

Figure 4. The percentage of gross domestic product (GDP) and employment in WNT (BPS NTB, 2014)

A possibility of the negative impacts of climate change on rice production in southern Indonesia, especially in WNT is supported by climate projections (IPCC, 2013). IPCC (2013) projects that mean temperature is likely to increase by about $0.3^{\circ} \mathrm{C}$ (by 2035) and $1.6{ }^{\circ} \mathrm{C}$ (by 2100) ${ }^{1}$ as seen in figure 5. IPCC (2013) also explains that Indonesia is projected to experience rainfall change. Figure 6 shows that northern and southern Indonesia is projected to have a different change on future rainfall. While northern Indonesia is projected to experience a higher precipitation about $10 \%$ (by 2046) and $20 \%$ (by 2100). Southern Indonesia regions such as WNT is projected to experience a lower rainfall between $-10 \%$ (by 2046) and $-20 \%$ (by 2100$)^{2}$.

\footnotetext{
${ }^{1}$ relative to the period 1986-2005 and based on RCP 4.5 scenario ${ }^{2}$ relative to the period 1986-2005 and based on RCP 4.5 scenario. 


\section{Methodology}

In this study, we advocate applying the system dynamics approach to detect systemic patterns in rice growth. System dynamics is renowned as a useful approach to explore and manage dynamic complex problem structures. The system dynamics (SD) approach offers qualitative (a causal loop diagram and system archetypes) and quantitative tools (stock-flow model i.e. computer-based simulation model). To capture systemic patterns, the SD approach handles feedback loops, non-linearity, delays, and system accumulation. More information about the SD approach can be found in a lot of handbooks (e.g. Sterman, 2000; Maani \& Cavana, 2007).

A lot of studies have proved that qualitative system dynamics tools is useful to analyze observed systems such as the water resource system (Mirchi, \& Watkins, 2012) and the agriculture (Nguyen, \& Bosch, 2013). Other studies also found that the qualitative system dynamics is useful in analyzing the Australia electricity market (Newell, Marsh, \& Sharma, 2011) and construction industry (Guo et al., 2015). This paper explains the application of the causal loop diagram and the system archetypes to identify (1) feedback loops; (2) system archetypes, and (3) possible solution to cope the negative impacts of climate change on rice production.

There are two types of the feedback loops including a reinforcing loop (R) and a balancing loop (B). Reinforcing loops represent growing in the observed system while balancing loops represent a self-correcting mechanism (Maani \& Cavana, 2007; Sterman, 2000). This study uses Vensim Plus® to translate a conceptual model into a causal loop diagram (CLD). Afterward, the system archetypes were identified based on an identified CLD. 


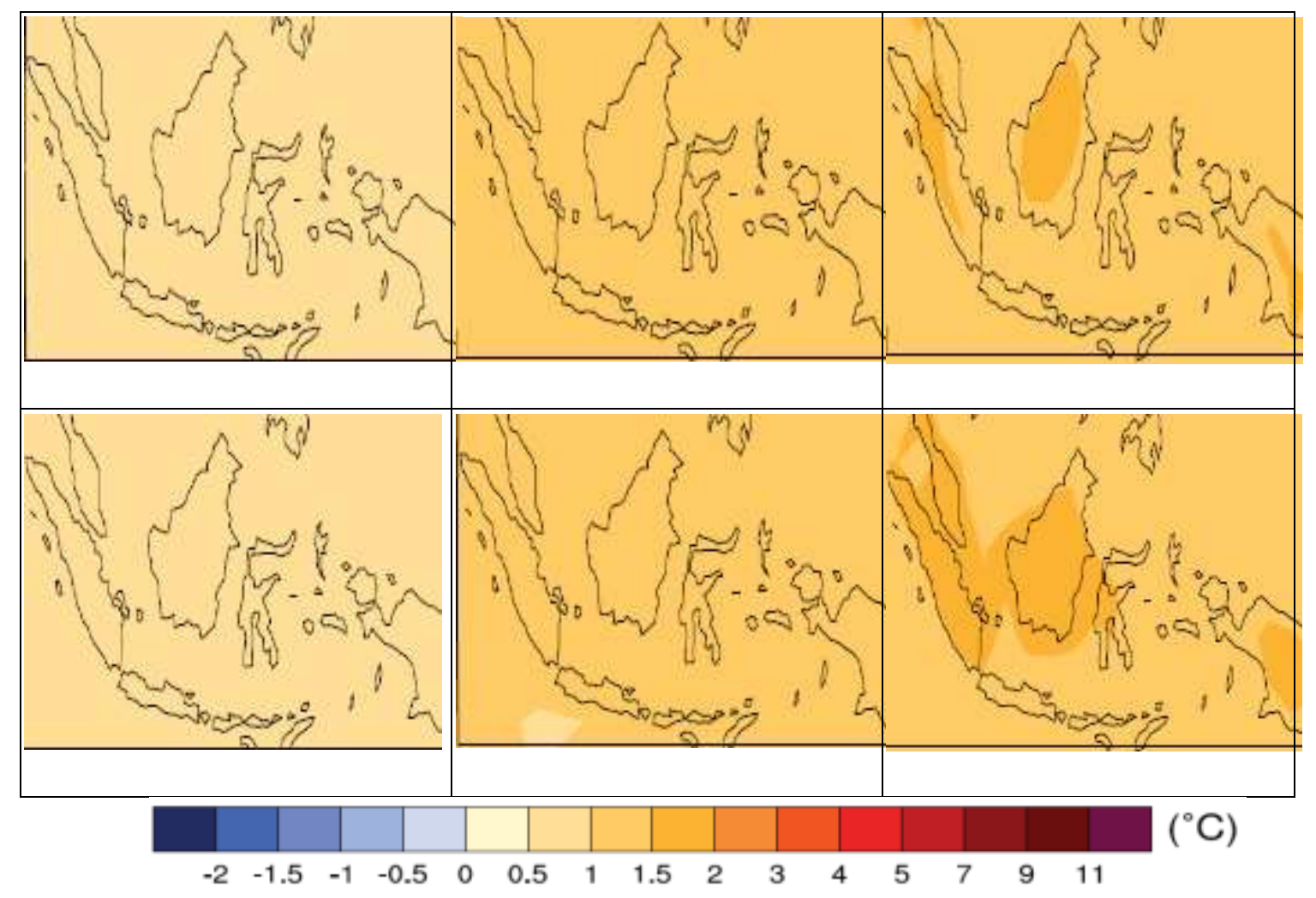

Figure 5. Projected temperature change in December-February (top) and June-August (bottom) relative to the period 1986-2005 for scenario RCP 4.5 with a median $50 \%$ of CMIP5 models. From left to right is the period 2016-2035, 2046-2065 and 2081-2100.

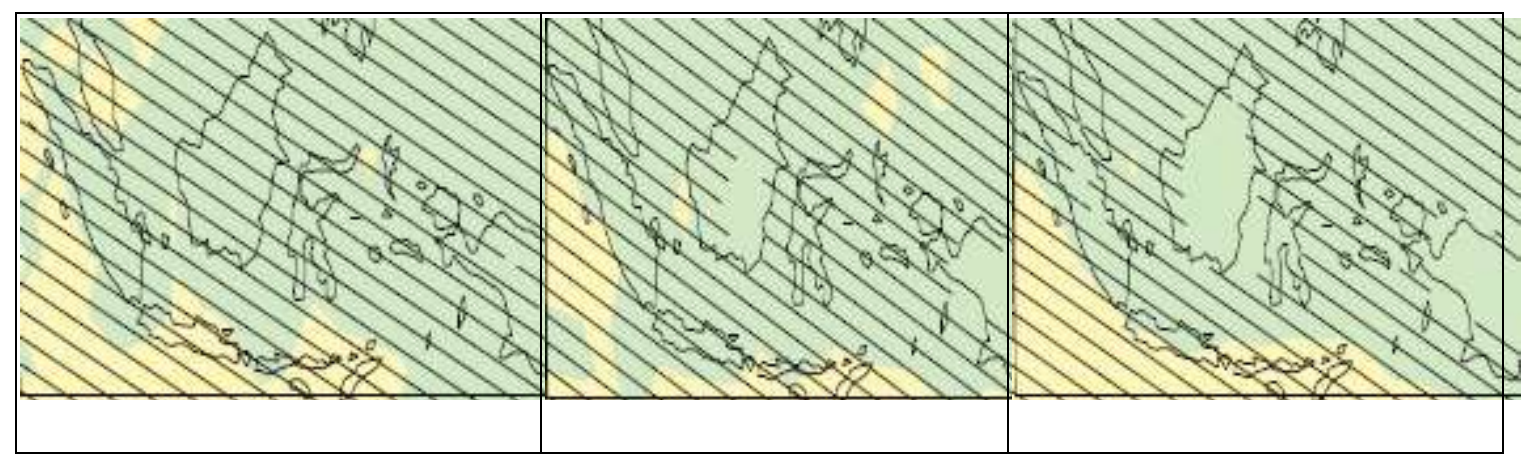




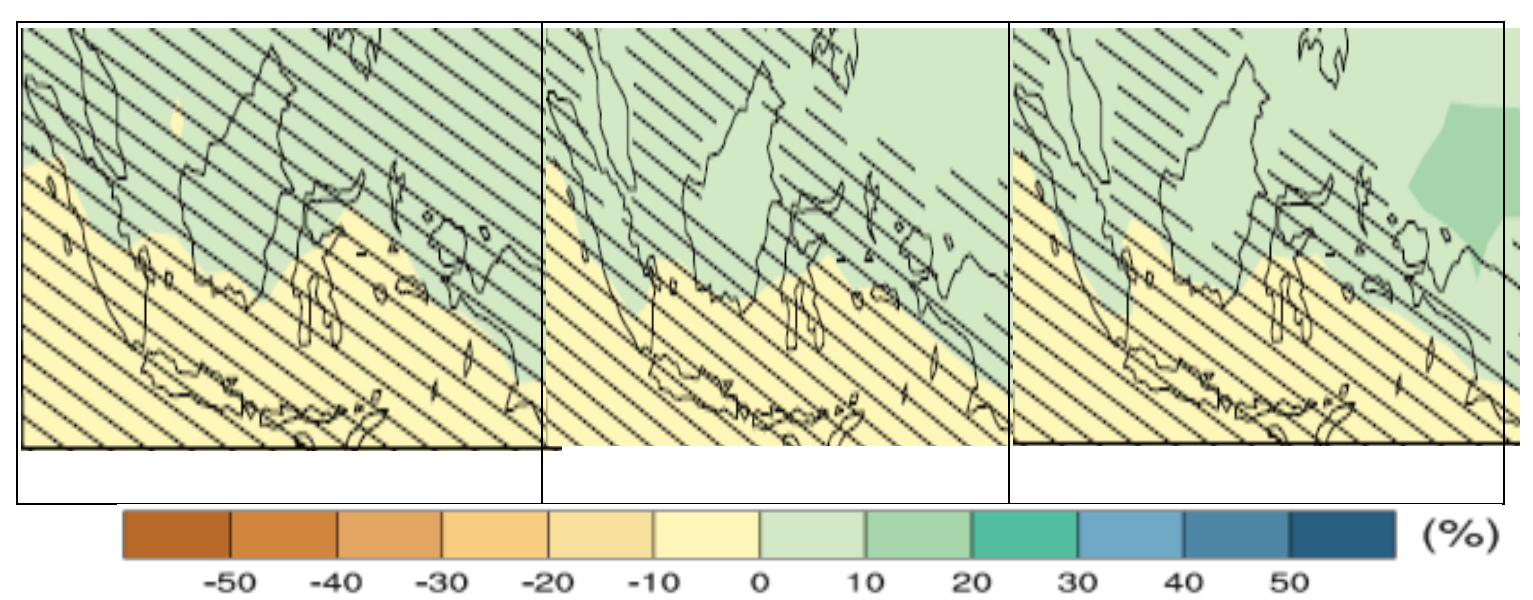

Figure 6. Projected rainfall change in October-March (top) and April-September relative to the period 1986-2005 for scenario RCP 4.5 with a median 50\% of CMIP5 models. From left to right is the period 2016-2035, 2046-2065 and 2081-2100.

The system archetypes are generic patterns of systems or templates that represent usual practices in our world. The system archetypes firstly were named by Senge (1991) in his book "The Fifth Discipline: The Art and Practice of the Learning Organization". Until this paper was written, there are about 10 archetypes such as Limits to Growth, Success to Successful, Shifting Burden and Escalation. The application of the system archetypes is very useful because they provide a simple insight of the system structures. A further discussion of the system archetypes can be seen in a lot of studies (e.g. Maani \& Cavana, 2007). Senge (2014) point outs that the system archetypes enable us to identify leverage points which in turn can improve the system performance.

\section{Results and discussion}

\subsection{A causal loop diagram of rice production}

It is widely known that three important variables such as carbon dioxide, precipitation and temperature could influence rice production (Ackerman \& Stanton, 2013; Lobell et al., 2011; Slingo et al., 2005). In general, a rising concentration of $\mathrm{CO}_{2}$ 
could enhance rice output because carbon dioxide is needed to synthesize organic compound supporting rice growth (Ackerman \& Stanton, 2013; Peng et al., 2004; Yoshida, 1981). Moreover, Falcon et al. (2004) affirm that precipitation is important for Indonesian rice production. In turn, rainfall variability could determine Indonesia rice production. Existing studies also (Ackerman \& Stanton, 2013; Lobell et al., 2011; Slingo et al., 2005) point out that the negative impacts of climate change on crops as climate change relates to high minimum temperature and high maximum temperature.

Figure 7 displays relationships among carbon dioxide $\left(\mathrm{CO}_{2}\right)$, precipitation, temperature and climate change. As noted previously, climate change associated with higher temperatures (IPCC, 2013), so a relationship between climate change and temperature (minimum and maximum temperature) has a “+” sign. As IPCC (2013), West Nusa Tenggara is projected to experience a lower precipitation so that a relationship between climate change and precipitation a “-” sign. Moreover, an increase in carbon dioxide is mainly caused by some factors such as land-use change and fossil fuel burning (IPCC, 2012), so fossil fuel burning and land-use change have a “+” sign with "climate change" respectively.

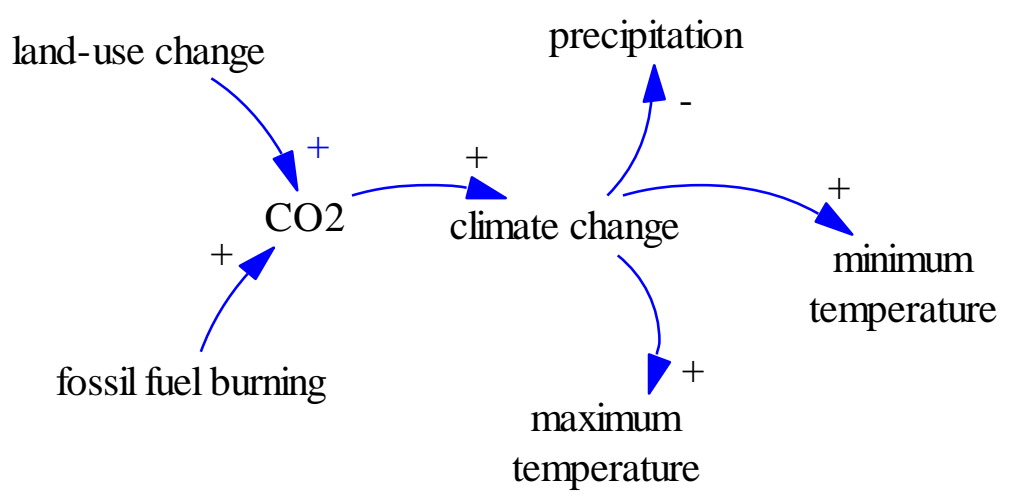

Figure 7. Relationships among $\mathrm{CO}_{2}$, climate change, temperatures, and precipitation 12 | P a g e 
Rice needs some chemical substances such as phosphorus, and nitrogen to grow properly (Li et al., 2012; Yoshida, 1981). Fertilizers and water (from reservoirs or rainfall) are main sources of these chemical elements. These chemical elements are important to increase photosynthesis rate (Yoshida, 1981). Together with chemical substances, carbon dioxide forms the assimilation pool through photosynthesis (Yoshida, 1981; Li et al., 2012). The assimilation then is converted to rice biomass such as a leaf. The relationships among water, photosynthesis, and fertilizer can be displayed in figure 8.

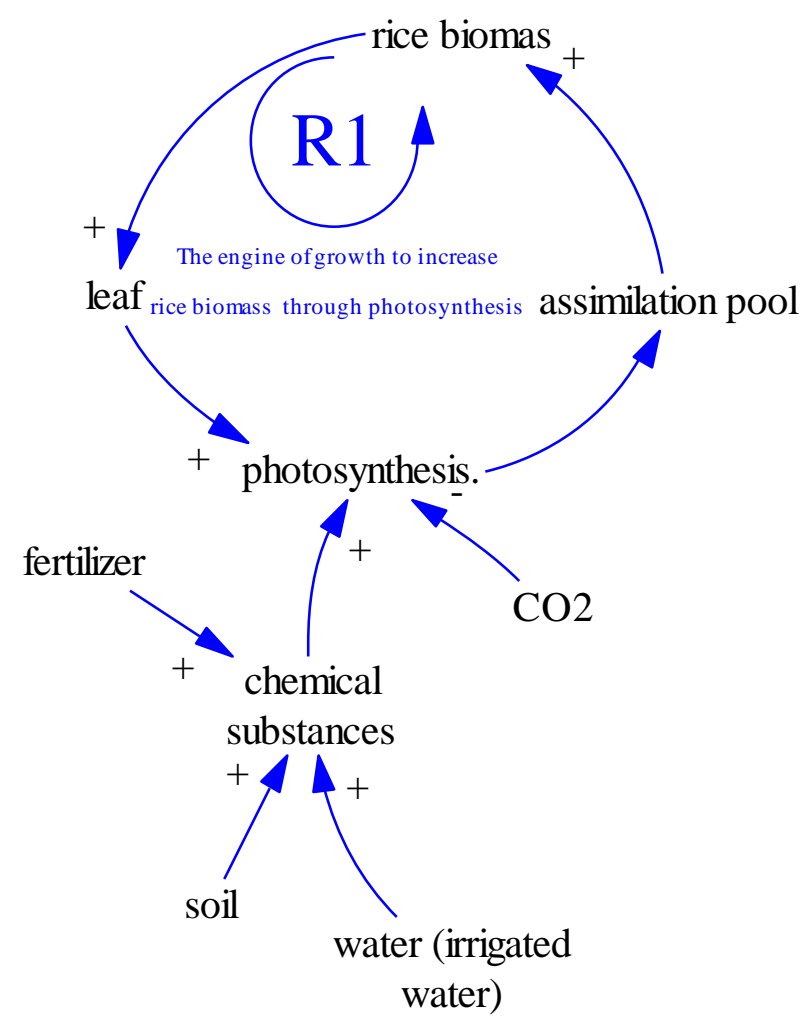

Figure 8. Photosynthesis 
As explained earlier, through photosynthesis, chemical substances are converted into assimilation pool to compose rice biomass (Yoshida, 1981). Afterward, rice biomass is converted to roots, stems, leave and panicle (Yoshida, 1981; Ministry of Science Technology \& Ministry of Environment \& Forest, 201; Li et al., 2012).

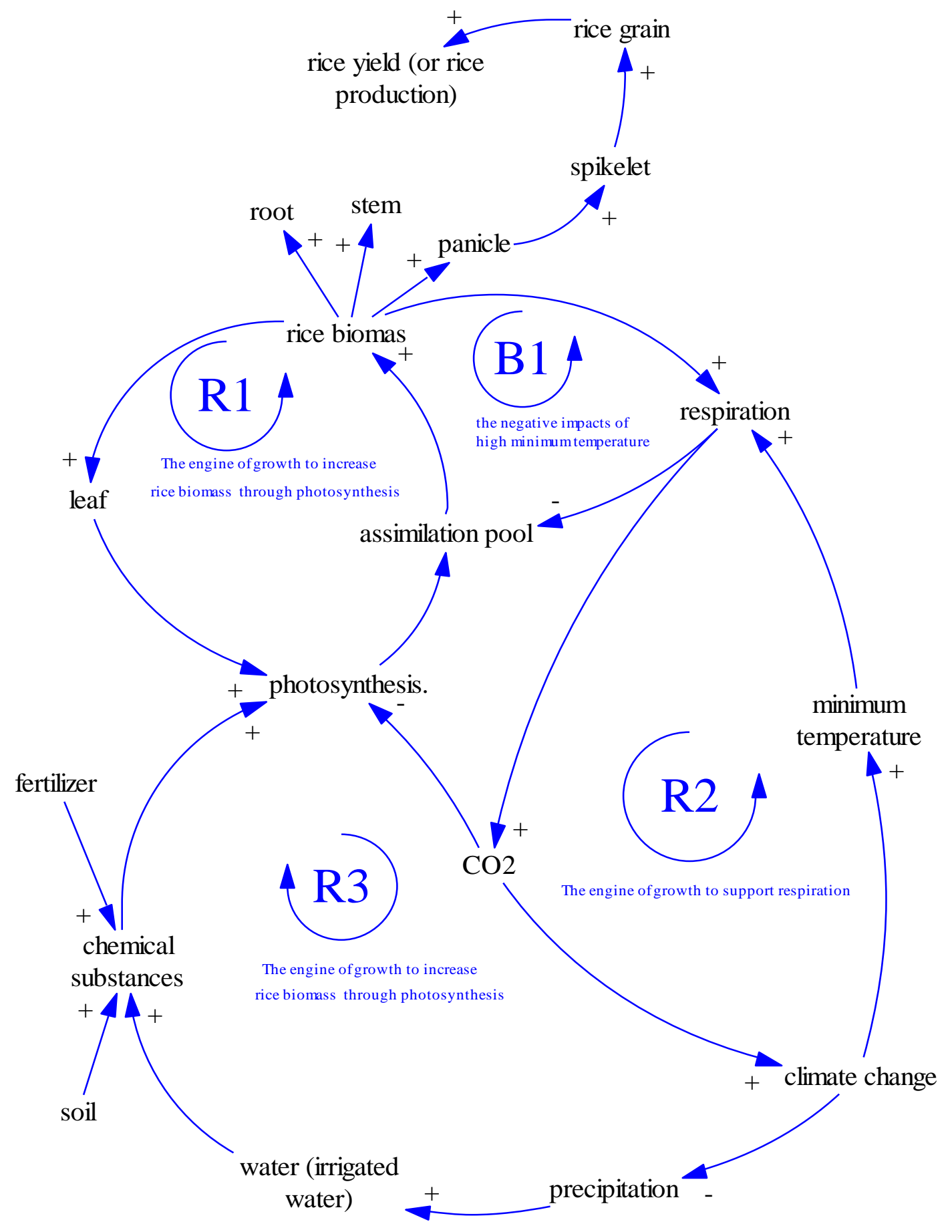


Figure 9. Photosynthesis and respiration mechanisms

Rice panicle is the main pillar for the spikelet growth. As panicles grow, spikelets occur on the top of the panicles. Rice panicle development is critical because it will affect the amount of panicle per farming area and rice grain per panicle (Ministry of Science Technology \& Ministry of Environment \& Forest, 2011).

To grow properly, rice also needs respiration. Rice respiration aims to sustain the ion concentration in crop cells and to turn over lipids and proteins (Mohammed \& Tarpley, 2009; Yoshida, 1981). The high minimum temperature could induce respiration, particularly if the minimum temperature exceeds a critical stage of $22^{\circ} \mathrm{C}$ (Peng et al., 2004; Mohammed \& Tarpley, 2009). However, respiration tends to decrease the amount of the assimilation pool so that there is less available assimilation pool to produce rice biomass (Mohammed \& Tarpley, 2009).

In addition to the impacts of temperature on rice, there are two ways of how higher temperatures could influence rice yield (Wassmann \& Doberman, 2007; Jagadish et al. 2010). The first is the maximum temperature higher than the maximum temperature threshold leads to spikelet sterility, decreasing rice yield (Jagadish et al. 2010; Wassmann \& Doberman, 2007). However, the negative impact of high maximum temperature can be negated by transpirational cooling through irrigated water (Jagadish et al., 2010; Wassmann \& Doberman, 2007). Secondly, the high minimum temperature is likely to increase respiration, decreasing the assimilation pool (Mohammed \& Tarpley, 2009). Figure 10 summarizes relationships between high minimum temperature, high maximum temperature and assimilation pool. 


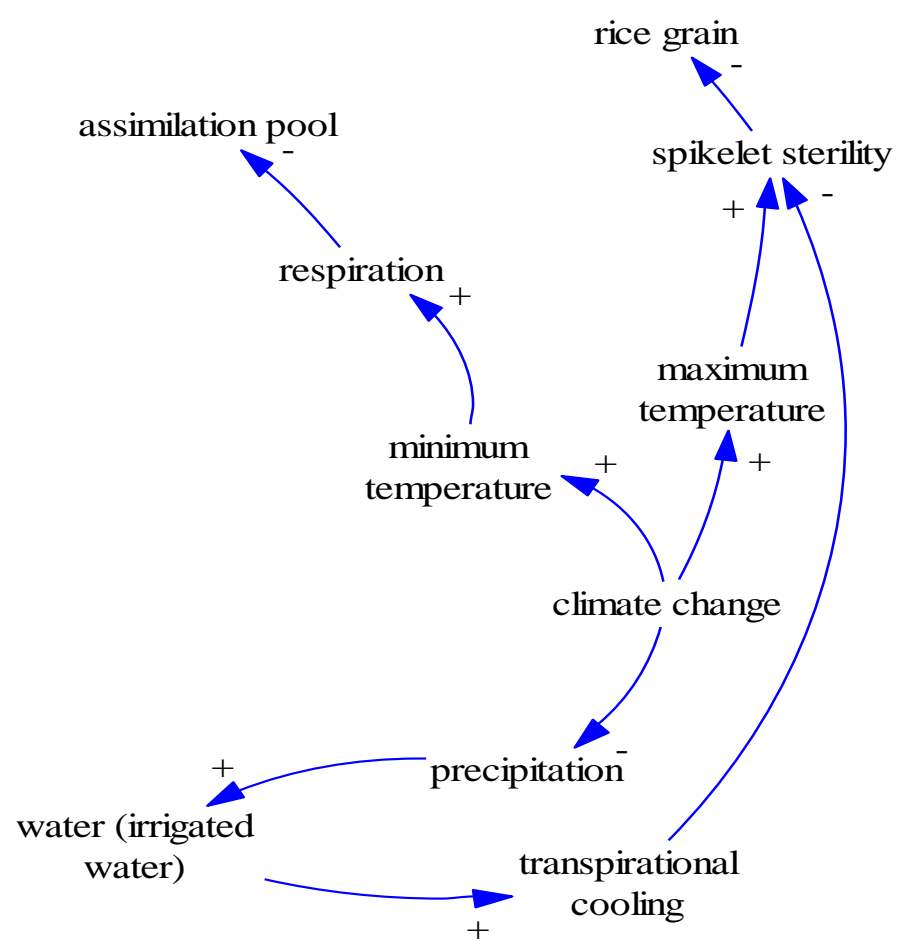

Figure 10. Respiration and temperature relationships

All figures between figure 7 and figure 10 can be combined into a complete causal loop diagram that reflects relationships among rainfall, high temperature, and rice production. Figure 11 shows a causal loop diagram of rice growth. The first reinforcing loop (R1) is a reinforcing loop that explains the accumulation of assimilation pool (photosynthesis - assimilation pool - rice biomass - leaf - photosynthesis). This loop (R1) asserts that photosynthesis continuously actives to increase rice biomass. 


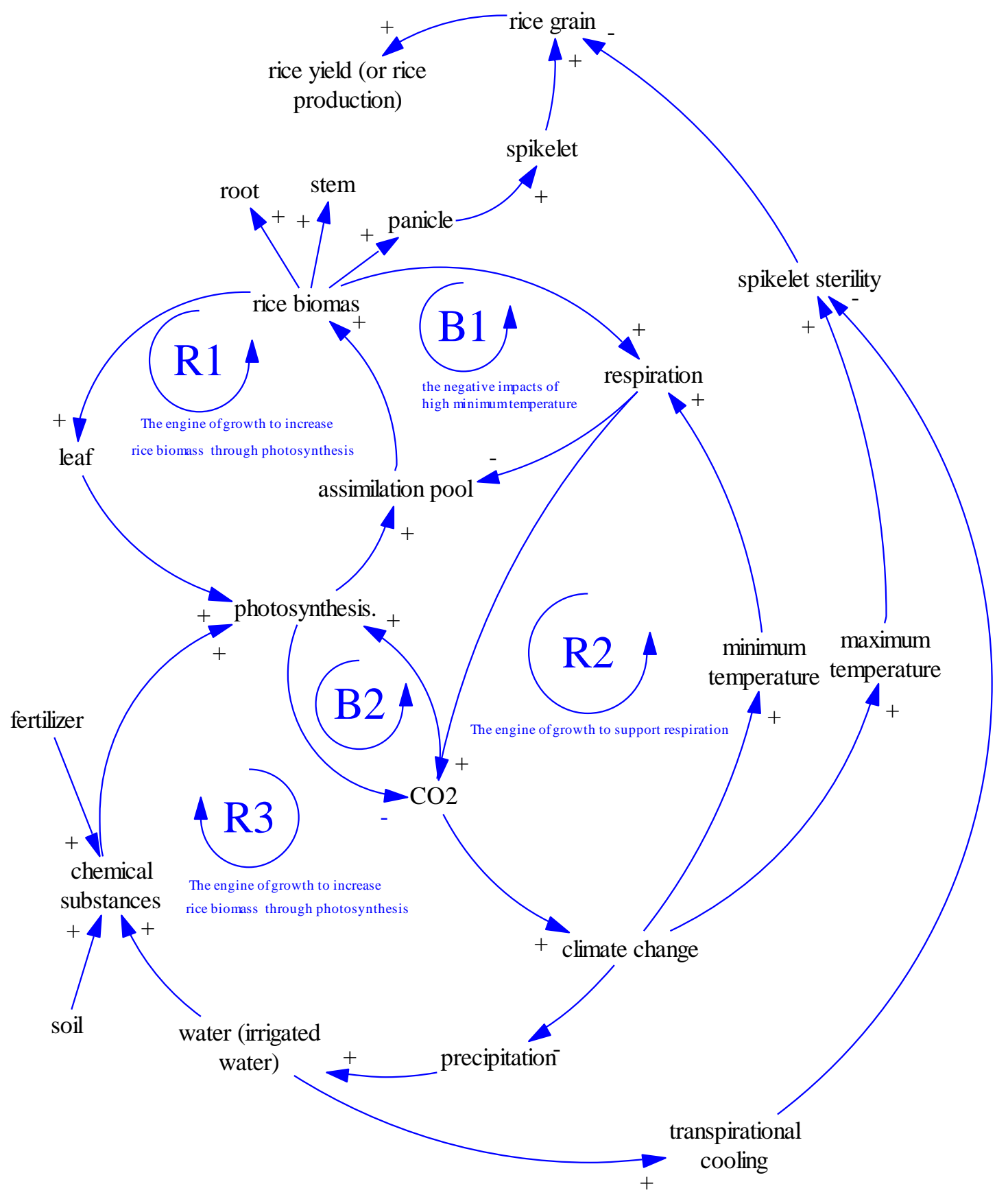

Figure 11. A complete causal loop relationship between climate change and rice production

The second reinforcing loop (R2) explains that high minimum temperature, owing to climate change, encourages respiration (respiration $-\mathrm{CO}_{2}-$ climate change - minimum temperature - respiration). The third reinforcing loop (R3) explains that photosynthesis 
continuously runs upon the availability of water and chemical substances (photosynthesis $-\mathrm{CO}_{2}$ - climate change - precipitation - irrigated water - chemical substances - photosynthesis).

The first balancing loop (B1) is a balancing loop that describes a respiration mechanism (rice biomass - respiration - assimilation pool - rice biomass). This balancing loop (B1) explains that respiration would decrease rice biomass through the respiration mechanism. The other balancing loop (B2) is "a clearing mechanism" where $\mathrm{CO}_{2}$ supports photosynthesis and in return, photosynthesis decreases $\mathrm{CO}_{2}$ availability.

\subsection{System Archetypes}

\section{The limits to growth}

After summarizing the causal loop diagram in figure 11, the author concludes two system archetypes. The first one is the limits to growth archetype and the second one is the success to successful. The limits to growth describe a process in which a period of accelerating growth is followed by a period of deceleration (Senge, 2006).

An increase in an assimilation pool through photosynthesis increases rice biomass (R1), leading to a higher rice production. This means that photosynthesis is the engine growth of rice production. However, a balancing loop (B1) negatively threatens rice production as a higher minimum temperature tends to increase respiration, decreasing an assimilation pool. Please keep in mind that under no climate change, respiration still occurs besides photosynthesis. However, the high minimum temperature increases respiration, leading to a lower rice production. 


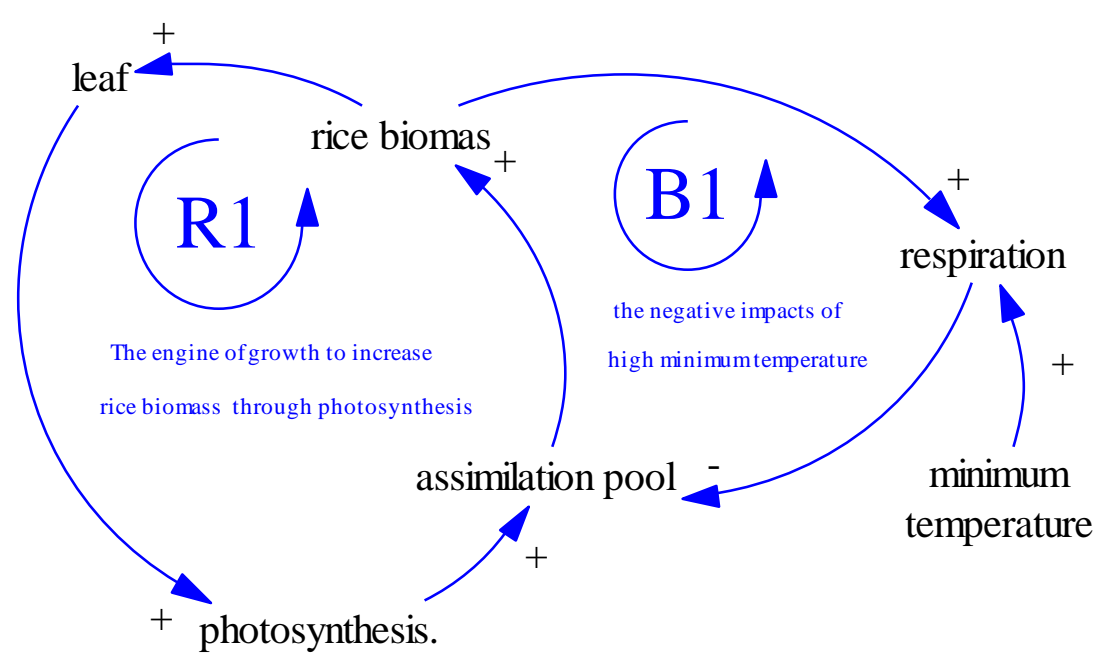

Figure 12. The limits to growth \#1

A lot of existing studies suggest finding leverage points that removing constraints to cope with negative impacts detected in the system archetypes (Nguyen, \& Bosch, 2013; Senge, 1991; 2014). One possible leverage point is to produce heat-tolerant rice varieties. Planting heat-tolerant varieties will likely to reduce the negative impacts of the high minimum temperature i.e. increasing respiration. Another leverage point is the mitigation of climate change, leading to low minimum temperature.

\section{The success to successful}

The second archetype detected is the success to successful as seen in figure 13. One activity has relatively greater success than the others, and consequently gains more support, while the poorer performer receives less support (Senge, 1991; 2014). The second reinforcing loop (R2) supports photosynthesis to increase rice biomass, leading a higher rice production. While the third reinforcing loop (R3) tends to support respiration, leading a lower rice production. 


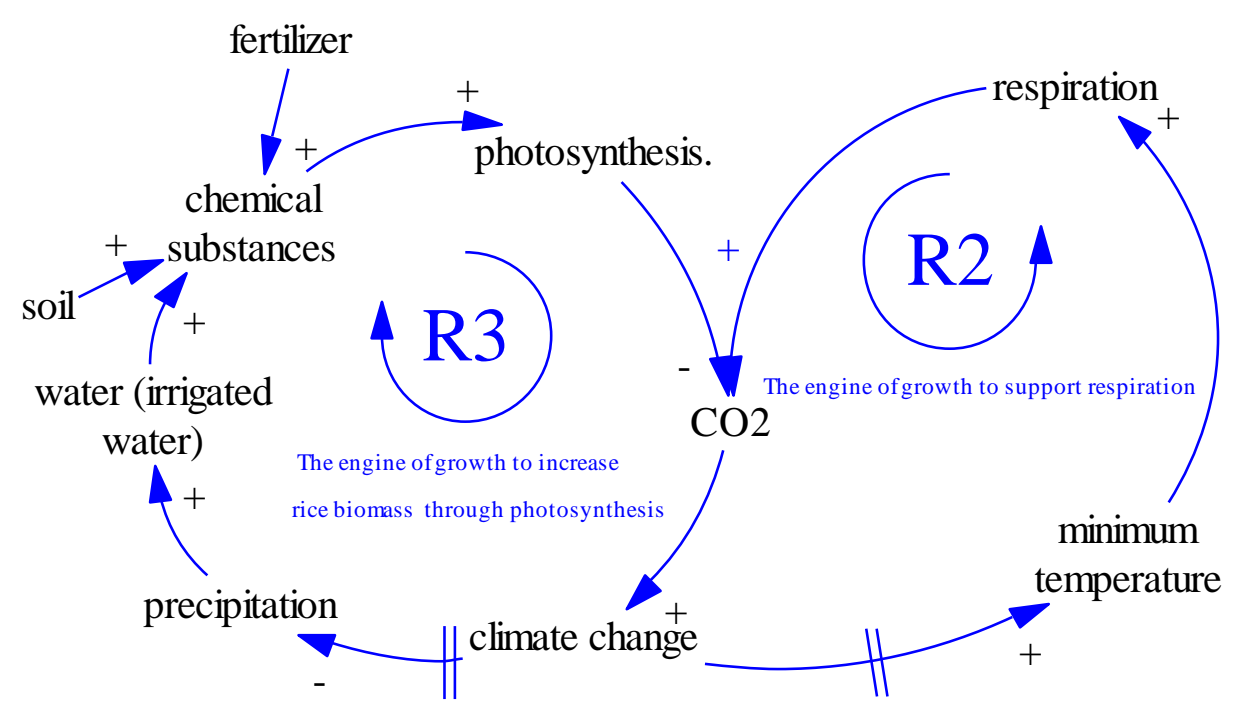

Figure 13. Success to successful \#1

Because the R3's growth engine is high minimum temperature, then solutions to support of increasing rice biomass is similar to the aforementioned solutions. That are, heat-tolerant rice varieties and the mitigation of climate change. If, for example, heattolerant rice varieties are already realized or mitigation of climate change is successful, then R2 will not exist. Please note that the engine of growth in R3 is irrigated water and chemical substances. Whereas the engine of growth in $\mathrm{R} 2$ is climate change i.e. elevated minimum temperature.

This study also captures another similar archetype as shown in figure 14. In this archetype, there is a competition to support photosynthesis between R1 and R3. This archetype explains that photosynthesis is supported upon the conversion of rice biomass to leaf (R1). This archetype also states that photosynthesis needs irrigated water and chemical substances (R3). In other words, photosynthesis requires chemical substances and water through the farm management (R3) and leaf (R1). 


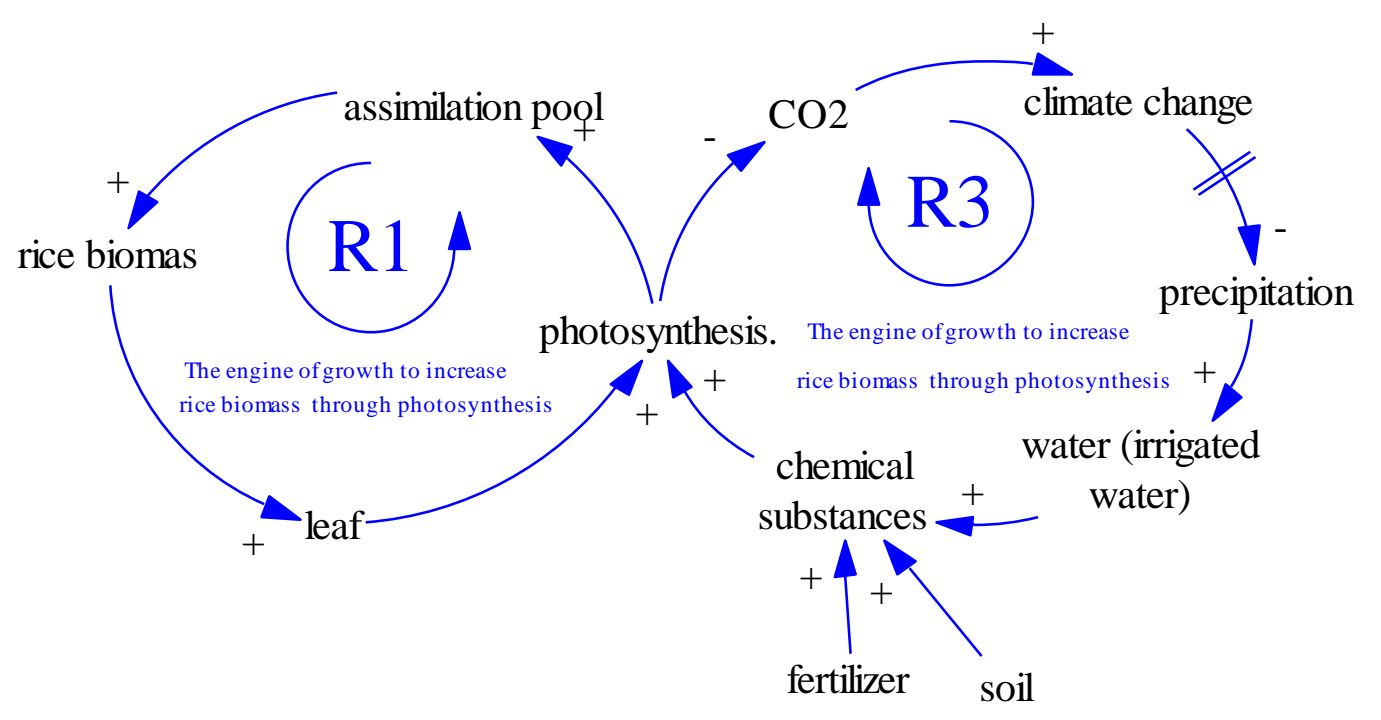

Figure 14. Success to successful \#2

\subsection{Comparing solutions}

A deep and throughout analysis of the possible solution is beyond the scope of this study. Nevertheless, this study discuss some updates on aforementioned solutions under a changing climate such as irrigation facilities and heat-tolerant rice varieties. Hopefully, this short analysis can broaden our perspectives in comparing possible solutions under a changing climate.

\section{Irrigation can decrease the negative impacts of high temperature}

Existing studies (Jagadish et al., 2010; Wang et al., 2012) suggest that irrigated water can decrease the ambient temperature, so the negative impacts of high temperature can be compromised. However, the positive impacts of irrigation facilities in minimizing the negative of high temperature is limited (Jagadish et al., 2010).

Irrigation facilities are, of course, important to expand and to guarantee rice production. Even better, reservoirs can increase rice growing seasons. Nevertheless, in the term of climate change impacts i.e. the negative impacts of high temperature, 
irrigation facilities can be seen as a short solution in minimizing the negative impacts of climate change on rice yield.

\section{Finding heat-tolerant rice varieties and the benefit of elevated $\mathrm{CO}_{2}$}

Some studies confirm the positive impacts of elevated $\mathrm{CO}_{2}$ emission on rice yield as elevated $\mathrm{CO}_{2}$ emission leads to increase in spikelet numbers (Kim et al., 2003; Yang et al., 2006; Zhang et al., 2013a). Those studies also urge us to realize the positive impacts of elevated $\mathrm{CO}_{2}$ on rice yield. However, other existing studies (Ainsworth, 2008; Zhang et al., 2013b) suggest finding heat-tolerant rice varieties before realizing the positive impacts of elevated $\mathrm{CO}_{2}$. This suggestion is owing to an experiment (Zhang et al., 2013b) showing that the negative impacts of high temperature will likely to negate the positive impacts of elevated $\mathrm{CO}_{2}$.

Heat-tolerant rice varieties are in high demand. This solution should be considered as a promising solution, especially after some studies (Kilasi et al., 2018; Tenorio et al., 2013; Ye et al., 2015) confirms that they successfully found genes or traits relate to heat tolerance. Moreover, finding heat-tolerant rice varieties is one-step ahead as trial experiments have been conducted to realize heat-tolerant rice varieties (https://www.philrice.gov.ph/heat-tolerant-rice-research-wins-outstanding-paper-award/ - accessed on August 9 $\left.{ }^{\text {th }}, 2019\right)$.

\section{Conclusion}

This study uses a simple tool, system archetypes, to identify the impacts of climate change on rice production. Using a causal loop diagram some interactions between climate and non-climate factors are described. The interaction among these factors regulates photosynthesis and respiration process during the rice growth. These interactions also capture the impacts of high temperature and rainfall change on rice 
production. Afterwards, identified system archetypes have been discussed to identify the impacts of climate change on rice production.

It seems that climate change could negatively affect rice production in the West Nusa Tenggara province. Climate change could negatively affect rice production through higher temperatures and decreasing precipitation. Meanwhile, the positive effect of $\mathrm{CO}_{2}$ is limited as its effect can be negated by the negative impacts of high minimum temperatures through respiration, leading to a lower biomass and rice production.

This study also provides a short analysis to identify a promising solution under a changing climate. While irrigation facilities can be a short-term solution, the mitigation policy needs a proper time to achieve. Owing to findings of genes relate to heat tolerance and on-going field experiments, heat-tolerant rice varieties is a promising solution to increase rice production under a changing climate.

Two main approaches in evaluating the impacts of climate change on crop production are crop models and statistical models (Lobell \& Burke, 2010; Lobell \& Asseng, 2017). While statistical models require less data, crop models require a lot of data such as daily temperature and daily rainfall. Please kindly note that statistical models can use monthly or seasonal climate to assess the impacts of climate change on crop production (Bahri, 2017; Lobell \& Burke, 2010). At one hand, crop models offer insights to the impacts of climate change during the crop growth (Lobell \& Burke, 2010).

The CLD in this study can be used as a starting point to develop a simulation model i.e. stock-flow model that accommodate strengths of crop and statistical models. This compromised model can enhance important processes during the rice growth as well as evaluating the impacts of climate change with fewer data than the crop models. 
Moreover, system archetypes explained in this study can be a basis to develop possible options or strategies to overcome the negative impacts of climate change on rice.

The last but not the least, considering that other main crops including wheat and corn have similar processes during their growth to the rice growth, this study offers two insights. The first, this study can be a basis to understand the impacts of climate change on other main crops and the second is this study also can be a basis to develop the simulation model for other crops. 


\section{References}

Ackerman, F., \& Stanton, E. A. (2013). Climate economics: the state of the art. Routledge.

Ainsworth, E. A. (2008). Rice production in a changing climate: a meta-analysis of responses to elevated carbon dioxide and elevated ozone concentration. Global Change Biology, 14(7), 1642-1650.

Bahri, M., K. (2017). Integrating Statistical and System Dynamics Modelling to Analyse the Impacts of Climate Change on Rice Production in West Nusa Tenggara, Indonesia (Doctoral dissertation, Victoria University of Wellington).

BMKG. (2011). Analisis Curah Hujan Bulan Desember 2010 dan Prakiraan Curah Hujan Bulan Februari, Maret Dan April 2011 Di Nusa Tenggara Barat. BMKG: Kediri, Indonesia.

BMKG. (2012). Analisis Curah Hujan Bulan Maret 2011 dan Prakiraan Curah Hujan Bulan Mei, Juni Dan Juli 2011 Di Nusa Tenggara Barat. BMKG: Kediri, Indonesia.

Dai, H., Xie, Y., Zhang, H., Yu, Z., \& Wang, W. (2018). Effects of the US withdrawal from Paris Agreement on the carbon emission space and cost of China and India. Frontiers in Energy, 12(3), 362-375.

Guo, B. H., Yiu, T. W., \& González, V. A. (2015). Identifying behaviour patterns of construction safety using system archetypes. Accident Analysis \& Prevention, 80, 125141.

Hadi, P. U., \& Susilowati, S. H. (2010). Prospek, Masalah dan Strategi Pemenuhan Kebutuhan Pangan Pokok. In Makalah dipresentasikan dalam Seminar Nasional Era Baru Pembangunan Pertanian: Strategi Mengatasi Masalah Pangan, Bioenergi dan Perubahan Iklim (Vol. 25).

IPCC. (2007). Climate change 2007-the physical science basis: Working group I contribution to the fourth assessment report of the IPCC (Vol. 4). Cambridge University Press.

IPCC. (2012). Managing the risks of extreme events and disasters to advance climate change adaptation. A Special Report Working Group I and II of The Intergovernmental Panel on Climate Change. Cambridge University: Cambridge and New York.

Jagadish, S.V.K., Sumfleth, K., Howell, G., Redona, R., Wassmann, R., \& Heuer, S. (2010).Temperature effects on rice: significance and possible adaptation.In Wassmann 
$\mathrm{R}$ (Eds). Advanced technologies of rice production for coping with climate change: 'no regret' options for adaptation and mitigation and their potential uptake (pp. 19-25). Manila: IRRI.

Kilasi, N. L., Singh, J., Vallejos, C. E., Ye, C., Jagadish, K., Kusolwa, P., \& Rathinasabapathi, B. (2018). Heat stress tolerance in rice (Oryza sativa L.): Identification of quantitative trait loci and candidate genes for seedling growth under heat stress. Frontiers in plant science, 9, 1578.

Kim H-Y, Lieffering M, Kobayashi K, Okada M, Mitchell MW, Gumpertz M. (2003). Effects of free-air CO2 enrichment and nitrogen supply on the yield of temperate paddy rice crops. Field Crops Research 83, 261-270.

Lawrence, M. G., \& Schäfer, S. (2019). Promises and perils of the Paris Agreement. Science, 364(6443), 829-830.

Li, T., Angeles, O., Marcaida, M., \& Manalo, E.(2012). Protocol for experimentation and data collection for modeling studies using ORYZA2000. IRRI: Los Banos, Philippines.

Lobell, D. B., \& Asseng, S. (2017). Comparing estimates of climate change impacts from process-based and statistical crop models. Environmental Research Letters, 12(1), 015001 .

Lobell, D., \& Burke, M. (2010). Climate change and food security: Adapting agriculture to a warmer world (Vol. 37). Springer Science \& Business Media.

Lobell, D. B., Schlenker, W., \& Costa-Roberts, J. (2011). Climate trends and global crop production since 1980. Science, 333(6042), 616-620.

Maani.K. \& Cavana.R.Y. (2007). Introduction to system thinking. Auckland, New Zealand: Pearson Education New Zealand

Ministry of Science \& Technology and Ministry of Environment \& Forest. (2011). Biology of Oryza Sativa. Ministry of Science \& Technology and Ministry of Environment \& Forest: India.

Mirchi, A., \& Watkins Jr, D. (2012). A systems approach to holistic total maximum daily load policy: case of Lake Allegan, Michigan. Journal of Water Resources Planning and Management, 139(5), 544-553. 
Mohammed \& Tarpley (2009). Impacts high night temperature on respiration, membrane stability, antioxidant capacity and yields of rice plants. Crop Science, 49(1), 313-322.

Naylor, R. L., Falcon, W., Wada, N., \& Rochberg, D.(2001). Using El Nino-Southern Oscillation climate data to rice production in Indonesia.Climatic Change, 50(3), 255265.

Naylor, R. L., Falcon, W., Wada, N., \& Rochberg, D.(2002). Using El Nino-Southern Oscillation climate data to improve food policy planning in Indonesia.Bulletin of Indonesian Economic Studies,Taylor and Francis Journals, 38(1), 75-91.

Naylor, R. L., Battisti, D. S., Vimont, D. J., Falcon, W. P., \& Burke, M. B. (2007). Assessing risks of climate variability and climate change for Indonesian rice agriculture. Proceedings of the National Academy of Sciences, 104(19), 7752-7757.

Naylor, R. L., \& Mastrandrea, M. D. (2009). Coping with Climate Risks in Indonesian Rice Agriculture: A Policy Perspective. In Uncertainty and Environmental Decision MakingA Handbook of Research and Best Practice(pp. 127-153). Filar, J. A., \& Haurie, A. Springer: New York. 2009.

Newell, E. B., Marsh, D. M., \& Sharma, D. (2011). Enhancing the resilience of the Australian national electricity market: Taking a systems approach in policy development.

Nguyen, N. C., \& Bosch, O. J. (2013). A systems thinking approach to identify leverage points for sustainability: a case study in the Cat $\mathrm{Ba}$ Biosphere Reserve, Vietnam. Systems Research and Behavioral Science, 30(2), 104-115.

Overpeck, J. T., \& Conde, C. (2019). A call to climate action. Science 364 (6443), 807.

Peng, S., Huang, J., Sheehy, J. E., Laza, R. C., Visperas, R. M., Zhong, X., \& Cassman, K. G. (2004). Rice yields decline with higher night temperature from global warming. Proceedings of the National Academy of Sciences of the United States of America, 101(27), 9971-9975

Senge, P. M. (1991). The fifth discipline, the art and practice of the learning organization. Performance+ Instruction, 30(5), 37-37.

Senge, P. M. (2014). The fifth discipline fieldbook: Strategies and tools for building a learning organization. Crown Business. 
Slingo, J. M., Challinor, A. J., Hoskins, B. J., \& Wheeler, T. R. (2005). Introduction: food crops in a changing climate. Philosophical Transactions of the Royal Society B: Biological Sciences, 360(1463), 1983-1989.

Sterman, J.D. (2001). Business dynamics: Systems thinking and modeling for a complex world. Boston, MA:Irwin McGraw Hill.

Tenorio, F. A., Ye, C., Redoña, E., Sierra, S., Laza, M., \& Argayoso, M. A. (2013). Screening rice genetic resources for heat tolerance FA TENORIO1, C. YE1, E. REDOÑA1, S. SIERRA1, M. LAZA1 AND MA ARGAYOSO1. sabrao J. Breed. Genet, 45(3), 371-381.

Wassmann, R., \& Dobermann, A. (2007). Climate change adaptation through rice production in regions with high poverty levels. Journal of Semi-Arid Tropical Agricultural Research, 4(1).

Welch, J. R., Vincent, J. R., Auffhammer, M., Moya, P. F., Dobermann, A., \& Dawe, D. (2010). Rice yields in tropical/subtropical Asia exhibit large but opposing sensitivities to minimum and maximum temperatures. Proceedings of the National Academy of Sciences, 107(33), 14562-14567.

Yang L, Huang J, Yang H, Zhu J, Liu H, Dong G, Liu G, Han Y, Wang Y. (2006). The impact of free-air $\mathrm{CO} 2$ enrichment (FACE) and $\mathrm{N}$ supply on yield formation of rice crops with large panicle. Field Crops Research 98, 141-150.

Yoshida, S.(1978). Tropical climate and its influence on rice. IRRI Research Paper Series 20. Los Baños, Philippines, IRRI.

Yoshida, S. (1981). Fundamentals of rice crop science. The International Rice Research Institute:Philippines.

Zhang, G., Sakai, H., Tokida, T., Usui, Y., Zhu, C., Nakamura, H., Yoshimoto, M., Fukuoka, M., Kobayashi, K. and Hasegawa, T. (2013a). The effects of free-air CO2 enrichment (FACE) on carbon and nitrogen accumulation in grains of rice (Oryza sativa L.). Journal of experimental botany, 64(11), pp.3179-3188.

Zhang, Y., Tang, Q., Peng, S., Zou, Y., Chen, S., Shi, W., Qin, J., \& Laza, M. R. C. (2013b). Effects of high night temperature on yield and agronomic traits of irrigated rice under field chamber system condition. Australian Journal of Crop Science, 7(1), 7. 